\title{
The Persuasive Effectiveness of Famous and Non Famous Endorsers in Advertising
}

\author{
Aïcha Meksi Gaied and Kaouther Saied Ben Rached \\ Faculty of Economic Science and Management of Tunis, Tunisia
}

\begin{abstract}
This research aims to compare the persuasive effectiveness and attitudes change induced in the case of famous and non famous endorser in advertisement. An experimentation was conducted by 290 tunisian women. Our empirical results showed that the non celebrity spokesperson was more credible and generated more favourable attitudes towards advertising, brand and purchase intent than celebrity spokesperson.
\end{abstract}

Keywords: Credibility - Famous /non famous characters- Advertising Persuasion

\section{Introduction}

To use an endorsement by celebrities is not a new phenomenon (Mehulkumar 2005). During, more than 50 years the advertising sector had used celebrities, Marilyn Monroe and Marlène Dietrich are famous examples (Iddiols 2002). This endorsement strategy owes its popularity to the development of radio advertising in the $30 \mathrm{~s}$, and the TV advertising in the 50s, so the cinema widened the extent of this strategy (McDonough 1995). In the late 70 's, this strategy continues to develop in a remarkable way. Today, the endorsement by the celebrities became a full element of the Marketing communications strategies (Erdogan 1999).

Numerous researches have proved empirically the effectiveness and the positive influence of the endorsements by the celebrities in advertising, particularly on endorser's credibility, message reminder, announcements approval and purchase's intention (Menon 2001, Pornpitakpan 2003, Pringle and Binet 2005, Roy 2006).
Of the fact their potential advantages in term of attention and reminder to message (Ohanian 1991, O'Mahony and Meenaghan 1997) celebrities endorsement can present a high risk and "no win situation" (celebrities's surrounding scandals, as those of Michael Jackson, Kate Moss and Britney Spears).

Some advertiser favour non famous endorsers. Tom and al (1992) noticed that created endorsers were more effective in creating a link to the product than celebrity endorsers. This requires a more detailed study of endorsement's strategy.

The objective of our research is to study: "Which strategy is most adapted through a televised advertising, in the case of a famous and non famous endorser?"

We will tend to answer two principal interrogations:

- What are the specific characteristics of celebrity and non celebrity which influence endorser's effectiveness in term of credibility, expertise and attractiveness? 
- What is the persuasive process by which an endorser (celebrity / non celebrity) affectattitude toward advertising, attitude toward brand and intentions to purchase in TV advertising

\section{Literature review}

According to McCracken (1989) definition "a celebrity endorser is a person who enjoys the public recognition and who uses this recognition in the name of goods while appearing with this one in advertising".

In the literature, two general models are often used to study celebrities endorsement effectiveness in advertising. At the beginning of the 50's, Hovland and his associates were turned to source's credibility model and to source's attractiveness model (McGuire 1968).

\subsection{The source credibility model}

A source is a person or an organization disseminating a message. The source's credibility is "the degree to which a viewer perceives the source to possess knowledge or an appropriate experience and do not provide biased information". Thus, two fundamental dimensions of source's credibility are: expertise and trustworthiness (Hovland and Weiss 1951).

Expertise is defined as « the extent to which a communicator is perceived to be a source of valid assertions" (Hovland, Janis and Kelly 1953). The communicator has the ability to make these reports (Hovland and Weiss 1951).

At the beginning of the eighty year in a context of sale, the results showed that the expert salesman induced a number of consumers significantly higher to buy the product, that induced by the inexpert salesman (Woodside and Devenport 1974). Trustworthiness is defined as "the degree of confidence in communicator' intend to communicate the assertions that he considers the most valid» (Woodside and Devenport 1974).
In certain circumstances the high source credibility and expertise were demonstrated to carry out a greater effectiveness (attitudes change and behavioral intention) that a low source credibility (Crano 1970, Kelman and Hovland 1953, Ross 1989). Other studies proved that there is no relationship between the expertise or the credibility level and the communication effectiveness (Bergin 1962, McGarry and Hendrich 1974).

This literature review leads us to put the first two hypotheses:

\section{H1: Perceived endorser credibility has a positive significant effect on: \\ - H1.1. the attitude towards the advertising, \\ - H1.2 the attitude towards the brand, and H1.3 the intention to buy.}

H2: Endorser expertise has a positive significant effect on:

- H2.1. the attitude towards the advertising,

- H2.2. the attitude towards the brand, H2.3. the intention to buy.

By using a perceptual judgment and operating the source expertise dimension, Crano (1970) showed that the subjects exposed to an expert source show more advertising appreciation than those exposed to low expertise treatment.

While a certain support was shown for the positive relationship between the source credibility and persuasion, other studies indicates that the high source credibility has not a greater persuasion as consequence (McGarry and Hendrich 1974, Rhine and Laurence 1970). The studies on credibility which concentrated on the expertise dimension, also failed to indicate the positive relationship between expertise and persuasion (Johnson and Steiner 1968). 


\subsection{The source attractiveness model}

The source attractiveness model is a component of the "source valence" (McGuire 1968).

This model showed that the communicator's message effectiveness depend on source "familiarity", "sympathy" and "similarity" with the receivers.

Similarity is the "degree to which a source is perceived as similar to the audience in terms of attitudes, opinion, activities, interests or lifestyle» (O'Mahony and Meenaghan 1997).

Many young male athletes are regarded as attractive sources with the same teenagers's genre. Familiarity is " the extent to which the audience members feel that they know endorser". Sympathy refers to the "presence or absence of the feelings which the message receiver would have towards the source information" (O'Mahony and Meenaghan 1997).

The physical attractiveness, the lively personality and the charisma play in the source agreement aspect.

Baker and Churchill (1977) noted that the use of attractive characters has a positive influence on the emotional reactions of advertising, contrary to the cognitive and conative reactions which prove to be negative. However, Petroshius and Crocker (1989) and O'Mahony and Meenaghan (1997) stipulated that attractive characters used in advertising lead to a more favourable attitude towards the advertising and to high purchasing intentions. The hypothesis 3 is then the following one:

\section{H3: Perceived endorser attractiveness has a positive significant effect on: \\ - H3.1. the attitude towards advertising, \\ - H3.2. the intention to buy.}

Kamins (1990) affirmed that an attractive celebrity is likely to be a particularly effective source of public image, because of the duel advantage: its celebrity statute and its attractiveness. In this same register,
Joseph (1982) declares that the physically attractive celebrities exert a positive effect on the evaluations and product's opinions. On the other hand, two other studies ( Caballero and Solomon (1984), Cabballero, Lumpki and Madden 1989) did not make it possible to detect an effect for the human model attractiveness and that human people with low/ moderate/ and high attractiveness do not affect the purchasing intention.

The two models have a major importance in the explanation of attributed characteristics to celebrities communicators, but certain the following authors McCracken (1989), Walker and al (1992) come to demonstrate the limits of these two models.

\subsection{Importance of source's characteristics on persuasion: the role of expertise and similarity}

Because of their considerable importance, communicator's characteristics (famous or not famous) "can increase or decrease the message potential to carry out attitude's or belief change" (Wilson and Sherell 1993). As we quoted already higher, for the credibility's characteristic, many research affirmed the principal effect of a credible source, and that "more the source is credible, more the message is persuasive" (Hovland and Weiss 1951, Kelman and Hovland 1953).

In their recent research, Goldsmith, Lafferty and Newell (2000) noted that "endorser credibility has an impact on the attitude towards advertising".

Of their share, O'Mahony and Meenaghan (1997) proved that "credibility towards communicator had the greatest impact on the purchase intention". In fact, endorsers which were considered to be very credible generated a high intention to buy the product. Ohanian (1991) also examined the impact of attractiveness, expertise and trustworthiness towards celebrities and respondents intention to buy the product. It found that attractiveness and trustworthiness towards celebrity were not related to purchase, without worrying if 
the purchase was for a personal use or a gift. However, expertise dimension was significantly linked with purchase.

A main interest was proven for the similarity characteristic with the endorser's message. Research contradictory results were also reported for similarity and its impact on persuasion. For example, Brock (1965) showed that similar sources achieve a higher behavioural change than the non similar sources.

As for Stafford (1998), he postulated that the intense similarity can, in fact, increase perceived confidence and credibility of endorser. The similarity expresses a variety of characteristics including the age, the gender, the social class, the educational level, the profession (Feick and Higgie 1992).

Alpert and Anderson (1973) examined the agreement degree between airline's companies and awarded declarations to various sources. A source moderate similarity with respondents carries out a high agreement degree, indicating that non optimal similarity could exist and generate a very effective communication. Leavitt and Karen (1975), also, reported a high agreement level in the presence of a source considered little similar, than that extremely similar.

\subsection{The Meaning transfer model}

According to McCracken (1989), these models do not take into account adequate distinctions between celebrities because those who are relatively similar in their credibility and attractiveness can produce various effects. According to McCracken, the source attractiveness and credibility model do not explain in detail "match-up" between celebrity and specific product or product category. He affirms that the combination of other factors such as cultural significances is important. Every celebrity represents a class, a statute, a personality, a lifestyle and a cultural category of gender and age, which are different for each endorser.
According to McCracken (1989), practitioner and researchers should concentrate on "the cultural significance" that each celebrity has.

Walker, Langemeyer and Langemeyer (1992) stressed that if celebrity endorser can indeed transmit its image to the products; there are limits to the final impact. For example, "the significance transferred by the mean of a celebrity is not necessarily translated into purchase intention" (p41).

In other words, although a celebrity can modify the perception toward the brand, that does not always lead to high level of sales. Furthermore, this meaning transfer may only occur with brands which have indefinite images. These critics interested the researchers to develop other ideal models such as the match-up hypothesis to answer as well as possible at appropriate fit between endorser and product.

\subsection{Effectiveness of celebrity endorser compared to a non celebrity endorser}

A recent evaluation indicates that almost $20 \%$ of all the advertisements in the whole world employ celebrities as spokespersons. Almost all the advertisers believe that "the messages transmitted by celebrities provide a higher degree of call, attention that those delivered by the non famous ones" (Cooper, 1984). Atkin and Block (1983) found that a famous communicator in advertising for an alcohol brand generate more favourable affectives responses than non famous communicator. However, advertising's credibility was higher under the condition of non famous communicator.

Of its share, Erdogan (1999) has concludes in the light of academic results that "famous endorsers are more effective than the non famous ones to influence the attitudes towards: advertising, endorsed brand, and purchase intentions. However, advertisers should use well celebrities who are congruent with brands and target public". We can put hypothesis 4 as follows: 
H4: Celebrity endorser has a more significant positif effect than a non celebrity endorser on :

- H4.1 the attitude towards the advertising,

- H4.2 the attitude towards the brand, H4. 3 purchase to buy.

However, Mehta (1994) postulated "that there was no significant difference for the concepts of attitude towards advertising, brand, and purchase intention for endorsed brands by celebrities and those endorsed by non celebrities". As for Mehta (1994), "once confronted to non famous endorsers, the consumers were significantly concentrated more on the brand and its characteristics, while with the famous endorser, the subject were significantly more concentrated on the celebrity in publicity"

\subsection{Conceptual model}

Exposure to TV advertising of a famous and non famous endorser

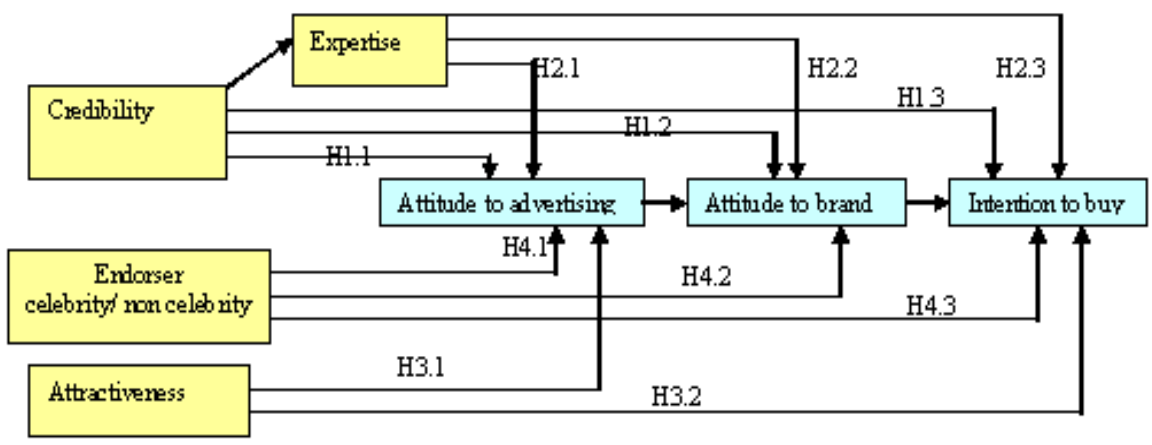

Fig 1. Conceptual model and research hypotheses

\section{Research Methodology}

We realized a quasi - experimentation which was led by 290 tunisian women having profile of present or potential consumer of the published products in TV advertising. This female target is old between 18 and 35 years.

Eight televised advertising for real brand had showed female spokespersons (famous / non famous) for 60 women. Two advertising were selected for our experimentation, which had the most raised scores and were appreciated better by respondents. The first television advertising showed a celebrity "Claudia Schiffer" endorsing an anti-wrinkle cream of «l'Oréal" brand. The second advertising exhibited a non celebrity "young girl" endorsing an anti-solar cream of "Olay" brand.

As asserts it, Rossiter (1982) "televised advertising mobilize 100\% of individual's attention, on the other hand printed advertisements attract only $46 \%$ of attention". To test reactions and attitudes which can be generated by real televised publicities, we had chosen the most seen spots by tunisian viewers from Arabic channels: "LBC and MBC" (according to SigMag on 2006) ${ }^{1}$.

The choice of real and familiar endorsed brands is justified to eliminate the artefact risk of the tested advertisements. This goes against certain researchers such as Muehling and Lacziniak (1988) who privileged advertisements with fictitious brand names to not bias study's results.

${ }^{1}$ SIGMAG : Sigma Magazine Media and Marketing Communication in Tunisia for the month of May 2006 


\subsection{Choice of product's category}

Our choice of product's category is explained by the fact that products of care and beauty included products to solve imperfections and defects of consumer's appearance (Brower and Landreth 2001). We can quote the care -body products, face or hair. This category occupied the second position after product food as regards investment in Tunisia (SigMag, May 2006). This confirms our published product's choice in the two commercials advertising: an anti-wrinkle cream and an anti-solar cream.

\subsection{Choice of female sample}

To respect the similarity between the endorser gender (celebrity/ non celebrity) and female respondents, we wished to not vary the celebrity sex and to choose televised advertisements with a female spokesperson promoting a product for a female use. What only confirms the choice of a women population.

\subsection{Choice of age bracket}

As we do not have a sounding base, the sampling method by convenience is adopted. Our choice of this method is explained by the fact that it is simple and practical to use, also we tried to exceed some limits met in the previous researches which consisted in targeting students considering their availability. We want to touch all the possible categories (students, liberal profession, employee, executive, worker, housewives), where an age bracket between 18 and 35 years is selected to represent all these categories as well as possible.

Table 1. Distribution of respondents

\begin{tabular}{|c|c|l|l|l|l|}
\hline \multicolumn{1}{|c|}{ Age } & $\mathbf{\%}$ & $\begin{array}{c}\text { Level of } \\
\text { study }\end{array}$ & \multicolumn{1}{|c|}{$\mathbf{\%}$} & \multicolumn{1}{|c|}{$\begin{array}{c}\text { Socio-professional } \\
\text { category }\end{array}$} & Percentage \\
\hline 18- 25 years & $44 \%$ & Primary & $3.7 \%$ & Student & $42 \%$ \\
25 - 35years & $40 \%$ & Secondary & $15.3 \%$ & Worker & $8.3 \%$ \\
35 years and + & $16 \%$ & Higher & $81 \%$ & Employee & $12.3 \%$ \\
& & & & Frame & $19.3 \%$ \\
& & & & Liberal profession & $9 \%$ \\
& & & & Others & 9 \\
\hline Total & $100 \%$ & & $100 \%$ & & $100 \%$ \\
\hline
\end{tabular}

\subsection{Choice of sample's number}

To guarantee good population representativeness, the sample size is determined in the following way given (Roussel and al 2002).

$\mathrm{N}=\mathrm{n} \times 10$ with $\mathrm{N}=$ sample size

$\mathrm{n}=$ number of items

By applying this formula, our sample is composed of 290 women.

\subsection{Experimental procedure}

The experimentation is carried out by a laptop and a high speaker. The visited places are varied: a sporting room, a hairdresser for woman, an aesthetician, primary school teachers, teachers in university. This variety of places allows us to meet groups of the women with different ages and professional socio- categories.

Respondents were exposed at two experimental conditions: each respondant is exposed to the first televised advertising presented by a celebrity, once she finishes to fill the first questionnaire, she will be exposed to the second televised advetising presented by a non celebrity.

Each questionnaire is auto- managed and lasts approximately 15 minutes.

\section{Research Results}




\subsection{Validity of chosen scales}

The measurement scale of each concept used in our model was taken from literature. Some of them were subject of French adaptations, whereas others were translated from English by "Back to back translation" technique by two bilingual people. We present the operationalization of constructs as following :

\section{Independent variables}

- To measure the celebrity's credibility, we used the credibility scale developed by Ohanian (1990). The source credibility scale is characterized by three dimensions: expertise (Coefficient Alpha $=0,893$ ), attractiveness (coefficient alpha = 0.832 ) and reliability (coefficient alpha $=0.832$ ). Each of source credibility dimensions is composed of 5 items measured on a bipolar scale on 7 points. We evaluated 15 items on a semantic differential scale on 7 points.
- To measure attitude toward advertising, we use scale of Baker and Churchill

(1977). This semantic differential scale is composed of 11 items measured on 7 point. It is a three- dimensional scale in the literature and characterised by affective, cognitive and conative attitudes. A principal component analysis with varimax rotation was conducted. Three items that represent cognitive attitude were eliminated from the scale because they represented poorly the studied phenomenon. Their elimination has also contributed to increase alpha's coefficient of attitude's scale (alpha = 0.877 ) which is very satisfactory. For affective attitude (Coefficient Alpha = 0,868 ) and conative attitude (Coefficient Alpha $=0,938$ ).

- To measure attitudes toward the brand in advertising, we use the scale of Till and Busler (2000). This scale is composed of 3 items and allows a Cronbach alpha with good value equal to 0.904 , which is very satisfactory.

\section{$\underline{\text { Dependent variables }}$}

Table 2:Effect of credibility on attitude toward advertising

\begin{tabular}{|c|l|c|c|c|c|c|c|}
\hline \multicolumn{2}{|c|}{} & \multicolumn{6}{c|}{ Dependent variable: Attitudes to advertising } \\
\cline { 3 - 8 } & & \multicolumn{2}{|c|}{$\begin{array}{c}\text { Unstandardized } \\
\text { coefficients }\end{array}$} & $\beta$ & t & Sig & $\mathrm{R}^{2}$ \\
\hline Model & & B & $\begin{array}{c}\text { Standard } \\
\text { error }\end{array}$ & & & & \\
\hline 1 & Constant & 5.639 & 2.071 & & 2.723 & 0.007 & \\
\hline & Credibility & 0.557 & 0.029 & 0.616 & 19.102 & 0.000 & 0.379 \\
\hline
\end{tabular}

\subsection{Results of Hypotheses}

Test of different hypotheses

According to table 2, the linear regression shows that credibility endorser has a positive significant effect on attitude towards advertising $(\mathrm{t}=19.10>0$, Sig $=$ $0.000<0.05$ ), thus the determination coefficient $\mathrm{R}^{2}=0,379$ means that perceived credibility of spokesperson explains $37.9 \%$ of publicity's attitude. What wants to say that most credible endorser (celebrity/ non celebrity) will generate a more favourable attitude to publicity.

The hypothesis H1.1 is confirmed. 
Table 3: Effect of credibility on the attitude to brand

\begin{tabular}{|l|l|c|l|l|l|l|l|}
\hline \multicolumn{2}{|c|}{} & \multicolumn{6}{|c|}{ Dependent variable: Attitude to brand } \\
\cline { 2 - 9 } \multicolumn{2}{|c|}{} & \multicolumn{2}{|c|}{$\begin{array}{c}\text { Unstandardized } \\
\text { coefficients }\end{array}$} & $\beta$ & $\mathrm{t}$ & Sig & $\mathrm{R}^{2}$ \\
\hline Model & & B & $\begin{array}{l}\text { Standard } \\
\text { error }\end{array}$ & & & & \\
\hline 1 & Constant & -1.281 & 1.233 & & -1.039 & 0.299 & \\
\hline & Credibility & 0.265 & 0.017 & 0.529 & 15.262 & 0.000 & 0.28 \\
\hline
\end{tabular}

It is deduced from this table that endorser's perceived credibility has a positive effect on attitude to the brand $(\mathrm{t}=15.26>0$, Sig $=$ $0.000<0.05)$, as $\mathrm{R}^{2}=0.28$ means that credibility explains $28 \%$ of attitude toward the brand. Therefore, more endorser is perceived to be credible more he generates more favourable attitudes toward the brand.

H 1.2 is confirmed.

Table 4: Effect of credibility on the intention to buy

\begin{tabular}{|c|l|c|c|c|c|l|l|}
\hline \multirow{2}{*}{} & \multicolumn{5}{|c|}{ Dependent variable : Intention to buy } \\
\cline { 3 - 8 } \multicolumn{2}{|c|}{} & \multicolumn{2}{|c|}{$\begin{array}{c}\text { Unstandardized } \\
\text { coefficients }\end{array}$} & $\beta$ & $\mathrm{t}$ & Sig & $\mathrm{R}^{2}$ \\
\hline Model & & $\mathrm{B}$ & Standard error & & & & \\
\hline 1 & Constant & -0.258 & 1.340 & & -0.192 & 0.848 & \\
\hline & Credibility & 0.255 & 0.019 & 0.484 & 13.53 & 0.000 & 0.234 \\
\hline
\end{tabular}

According to results of table 4, we note that endorser credibility (famous and non famous) has a significantly positive effect on purchase intention $(\mathrm{t}=13.53>0$, Sig $=$ $0.00<0.05$ ), as $\mathrm{R}^{2}=0.234$ means that credibility explains $23.40 \%$ of purchase intention. We can say that more endorser is perceived credible most he induces favourable intention to buy.

H1.3 is confirmed.

Table 5: Effect of expertise on the attitude toward the advertising

\begin{tabular}{|c|c|c|c|c|c|c|c|}
\hline & \multicolumn{6}{|c|}{ Dependent variable : Attitude to the advertising } \\
\hline & & \multicolumn{2}{|c|}{$\begin{array}{l}\text { Unstandardized } \\
\text { coefficients }\end{array}$} & \multirow[t]{2}{*}{$\beta$} & \multirow[t]{2}{*}{$\mathrm{t}$} & \multirow[t]{2}{*}{ Sig } & \multirow[t]{2}{*}{$\mathrm{R}^{2}$} \\
\hline Model & & B & Standard error & & & & \\
\hline 1 & Constant & 21.75 & 1.896 & & 11.47 & 0.000 & \\
\hline & Expertise & 10.46 & 0.086 & 0.450 & 12.33 & 0.000 & 0.203 \\
\hline
\end{tabular}

Table 5 shows that expertise influences in a significant way attitude toward advertising and this is confirmed by $(\mathrm{t}=12.33>0 \mathrm{Sig}=$ $0.00<0.05$ ) and $\mathrm{R}^{2}=0,203$, it means that perceived expertise toward endorser explains $20.30 \%$ of advertising attitude. More endorser is perceived as expert, he induces a more favourable attitudes towards publicity. H2.1 is confirmed. 
Table 6: Effect of expertise on the attitude towards brand

\begin{tabular}{|c|c|c|c|l|l|l|l|}
\hline & & \multicolumn{5}{|c|}{ Dependent variable : Attitude toward the brand } \\
\hline & \multicolumn{2}{|c|}{$\begin{array}{c}\text { Unstandardized } \\
\text { coefficients }\end{array}$} & $\beta$ & $\mathrm{t}$ & Sig & $\mathrm{R}^{2}$ \\
\hline Model & & $\mathrm{B}$ & Standard error & & & & \\
\hline 1 & Constant & 4.697 & 1.050 & & 4.473 & 0.000 & \\
\hline & Expertise & 0.575 & 0.047 & 4.448 & 12.23 & 0.000 & 0.200 \\
\hline
\end{tabular}

The source expertise has a positive significant towards the attitude to the brand $(\mathrm{t}=12.23>0$
Sig $=0.00<0.05$ ) and $\mathrm{R}^{2}=0,200$. It means to say that expertise explains $20 \%$ of the attitude toward the brand.

H2.2 is confirmed.

Table 7: Effect of expertise on intention to purchase

\begin{tabular}{|c|c|c|c|l|l|l|l|}
\hline \multicolumn{2}{|c|}{} & \multicolumn{6}{|c|}{ Dependent variable : Intention to buy } \\
\cline { 3 - 8 } \multicolumn{2}{|c|}{} & \multicolumn{2}{|c|}{$\begin{array}{c}\text { Unstandardized } \\
\text { coefficients }\end{array}$} & $\beta$ & $\mathrm{t}$ & Sig & $\mathrm{R}^{2}$ \\
\hline Model & & $\mathrm{B}$ & Standard error & & & & \\
\hline 1 & Constant & 7.19 & 1.158 & & 6.207 & 0.000 & \\
\hline & Expertise & 0.477 & 0.052 & 0.352 & 9.208 & 0.000 & $\begin{array}{l}0.12 \\
4\end{array}$ \\
\hline
\end{tabular}

Table 7 reveals that expertise has positive and significant influence to purchase intention. The more endorser is perceived as expert, he will induced more favourable intentions to purchase, with $(\mathrm{t}=9,208>0$ Sig $=0.00<0.05$ ) and $\mathrm{R}^{2}=0,124$, it means that expertise influences $12.40 \%$ of the purchase intention.

H2.3 is confirmed.

Table 8 : Effect of attractiveness on attitude toward the advertising

\begin{tabular}{|c|c|c|c|l|l|l|l|}
\hline \multicolumn{2}{|c|}{} & \multicolumn{5}{|c|}{ Dependent variable : Attitude toward the advertising } \\
\cline { 3 - 9 } & & \multicolumn{2}{|c|}{$\begin{array}{c}\text { Unstandardized } \\
\text { coefficients }\end{array}$} & $\beta$ & $\mathrm{t}$ & Sig & $\mathrm{R}^{2}$ \\
\hline Model & & $\mathrm{B}$ & Standard error & & & & \\
\hline 1 & Constante & 16.64 & 2.168 & & 7.678 & 0.000 & \\
\hline & Attractiveness & 1.214 & 0.093 & 0.473 & 13.12 & 0.000 & 0.224 \\
\hline
\end{tabular}

According to this table, attractiveness has a positive effect on the attitude to advertising. An attractive endorser generates a favourable attitude towards publicity (with $\mathrm{t}=13.12>0 \mathrm{Sig}=$
$0.00<0.05$ ) and $\mathrm{R}^{2}=0,225$. The attractiveness explains $22.40 \%$ of the attitude toward publicity. $\quad \mathrm{H} 3.1$ is confirmed. 
Table 9 : Effect of attractiveness on intension to purchase

\begin{tabular}{|c|c|c|c|c|l|l|l|}
\hline \multicolumn{2}{|c|}{} & \multicolumn{5}{|c|}{ Dependent variable : Intention to buy } \\
\cline { 3 - 8 } \multicolumn{2}{|c|}{} & \multicolumn{2}{|c|}{$\begin{array}{c}\text { Unstandardized } \\
\text { coefficients }\end{array}$} & $\beta$ & $\mathrm{t}$ & Sig & $\mathrm{R}^{2}$ \\
\hline Model & & $\mathrm{B}$ & $\begin{array}{c}\text { Standard } \\
\text { error }\end{array}$ & & & & \\
\hline 1 & Constant & 5.860 & 1.348 & & 4.345 & 0.000 & \\
\hline & Attractiveness & 0.510 & 0.058 & 0.341 & 8.868 & 0.000 & 0.116 \\
\hline
\end{tabular}

The attractiveness has a significantly positive influence towards purchasing intention (with $\quad \mathrm{t}=8,868>0 \mathrm{Sig}=$ $0.00<0.05$ ) and $\mathrm{R}^{2}=0,116$. The attractiveness explains $11.6 \%$ of intention to purchase. What proves that an attractive endorser generates more favourable intentions to purchase.

H 3.2 is confirmed.

Table 10: Effect of the presence of celebrity endorser compared to a non celebrity endorser on Aad, $\mathrm{Ab}$ and $\mathrm{Ib}$

\begin{tabular}{|c|c|c|c|c|}
\hline & $\mathrm{N}$ & $\begin{array}{c}\text { Average scores } \\
\text { Aad }\end{array}$ & $\begin{array}{c}\text { Average } \\
\text { scores Ab }\end{array}$ & $\begin{array}{c}\text { Average scores } \\
\mathrm{Ib}\end{array}$ \\
\hline $\begin{array}{c}\text { Advertising 1: } \\
\text { Celebrity endorser }\end{array}$ & 290 & 43.65 & 17.32 & 17.49 \\
\hline $\begin{array}{c}\text { Advertising 2: } \\
\text { Non celebrity } \\
\text { endorser }\end{array}$ & 290 & 45.60 & 17.20 & 17.62 \\
\hline $\begin{array}{c}\text { Signification } \\
\text { ignion }\end{array}$ & $\begin{array}{c}\mathrm{F}=4.907 \\
(\mathrm{p}=0.027)\end{array}$ & $\begin{array}{c}\mathrm{F}=0.057 \\
(\mathrm{p}=0.812)\end{array}$ & $\begin{array}{c}\mathrm{F}=0.267 \\
(\mathrm{p}=0.606)\end{array}$ \\
\hline
\end{tabular}

According to the results above, there exists a significant difference for the average scores obtained for attitude toward advertising, in the case of celebrity and non celebrity endorser $(43.65<45.60)$. We note a significant value of $\mathrm{F}(\mathrm{p}=0.027$ $<0.05$ ). We can conclude that the women exposed to advertising by a non celebrity generated more favourable attitudes towards advertising than those generated by a celebrity. Which cancels our hypothesis, H4.1 is cancelled.

- For the scores obtained of attitude toward the brand (17.32 and 17.20), there isn't any significant difference for female respondents attitudes toward the brand in the case of famous and non famous endorser. The value of $\mathrm{F}$ is weak and non significant $(p=0,812>0.05)$ indicating a similarity of responses for both advertisements. H4.2 is cancelled .

- The scores obtained for purchase intentions of respondents are similar (17.49 and 17.62) for two publicities. With weak value of $F$ and non significant $(p$ $=0.606>0.05$ ). Indicating that the respondents expressed the same probability to purchase promoted brand. H4.3 is rejected.

According to our results, it proves that insertion of a celebrity can represent future risks for advertisers. Thus, through our empirical results a non famous endorser generates more favourable attitudes towards publicity, brand and intention to purchase that those generated by a celebrity. This underlined the major and considerable importance for 
practitioner of advertising. These results can be explained by the effect of similarity perceived between non famous endorser and females respondents in term of statute, age and sex. What produced very favourable influence towards the advertising effectiveness and endorser persuasion as a communicator.

\section{Conclusion}

Our research showed the persuasive power of non famous endorser's credibility as a major asset to reinforce advertising effectiveness. The advertisers should exploit it in their messages, to guarantee a favourable attitude toward advertising and the promoted brand of the target public.

We agreed that famous endorser strategy is used in international scale, considering its effectiveness and its repercussions of sale which it generates.

Hence, our research demonstrated that non celebrity endorsement is more appreciated than celebrity endorsement and induced more positive attitudes. What questions the frequent and increasing use of famous endorsers. Until this level, we can affirm that "match-up " between endorser and receiver is a determining factor for advertising's persuasive effectiveness.

\section{Research limits}

Our research presents some limits which touch conditions exposure and familiarity with the brand presented in the selected TV advertisements:

- Although the two TV advertising were chosen and presented under favourable conditions, an absence of natural exposure took place: considering the lack of insertion of a televised program in our experimentation. This lack can increase the attention degree at answering, which can be considered to be higher in the event of natural exposure.

- Familiarity with brands presented in the two advertising (the first brand of " l'Oréal "presented by Claudia Schiffer and the second brand of "Olay" presented by a non famous endorser), can present cognitive bias in term of attitude toward the promoted brand.

- An external validity problem, considering our sample is chosen by convenience. But, according to Thiétart and all. (2003) the internal validity is priority.

\section{Research perspectives}

1- Examine in the case of celebrity and non celebrity, attitude towards an unknown brand for other product categories and see the impact of affective, cognitive and conative attitudes it can generate.

2- Study the possible role of famous and non famous spokesperson presence with other advertising strategies such as the emblem and allegory for identifying the persuasive impact which it can generate.

3- Enclose other variables such as age, gender, involvement toward the product.

\section{References}

Alpert, MI and Thomas.A. (1973), «Optimal Heterophily and Communication Effectiveness, Some Empirical Findings", Journal of Communication September (23), 328-43.

Atkin, C and Block, M. (1983), "Effectiveness of Celebrity Endorses ", Journal of Advertising Research February/ March, 57-61.

Baker, MJ and Churchill, GA. (1977) « The Impact of Physically Attractive Models on Advertising Evaluations», Journal of Marketing Research November (14), 538555.

Bergin, A. (1962) «The Effect of Dissonant Persuasive Communication Upon Change in Self-Referring Attitude", Journal of Personality (30), 423-38.

Brock, T. (1965) «Communicator Recipient Similarity and Similarty and Decision Change", Journal of Personality and Social Psychology (1), 650-54.

Caballero, MJ and Solomon, PJ. (1984), "Effects of Model Attractiveness on Sales Responses", Journal of Advertising 13 (1), 17-23. 
Cabballero, MJ. Lumpkin, JR. and Madden, CS. (1989), " Using Physical Attractiveness as an Advertising Tool: An Empirical Test of the Attraction Phenomenon", Journal of Advertising Research August/ Septempber 29,16-22.

Cooper, M. «Can Celebrities Really Sell Products? » Marketing and Media Decisions, (19) September (1984), 64-5.

Brower, A.and Landreth, S. (2001), «Is Beauty Best? Highly versus Normally Attractive Models in Advertising", Journal of Advertising 30 (1), 1-12.

Crano, W. (1970), "Effects of Sex, Response Order, and Expertise in Conformity: A Dispositional Approach", Sociometry September 33, 239-52.

Erdogan, BZ. (1999), “Celebrity Endorsement: A Literature Review", Journal of Marketing Management 15 (4), 291-314.

Feick, L and Higgie RA. (1992), «The Effects of Preference Heterogeneity and Source Characteristics on Ad Processing."Journal of Advertising June 21 (2), 9-24.

Goldsmith,RE., Lafferty, BA and Newel, SJ. (2000) «The Impact of Corporate Credibility and Celebrity Credibility on Consumer Reaction to Advertisements and Brands", Journal of Advertising, 29 (3), 4354.

Hovland, CI and Weiss, W. (1951), "The Influence of Source Credibility on Communication Effectiveness", Public Opinion Quartely15, 635-650 in Ohanian, R. (1990) « Construction and Validation of a Scale to Measure Celebrity Endorsers Perceived Expertise, Trustworthiness and Attractiveness", Journal of Advertising 19 ( 3), 39-52.

Hovland, CI, Janis, IL and Kelly, HH. (1953).Communication and Persuasion: Psychological Studies of Opinion Change, New Haven: Yale University Press, in Ohanian, R. (1990),

Construction and Validation of a Scale to
Measure Celebrity Endorsers Perceived Expertise, Trustworthiness and Attractiveness", Journal of Advertising 19 (3), 39-52.

Iddiols, D. (2002), « The Fame game: Using Celebrities Effectively », World Advertising Research Center 37 (11), 1-3.

Johnson, H and Steiner, I. (1968), "The Effects of Source on Source on Responses to Negative Information about One's Self", Journal of Social Psychology August, 215224.

Joseph, WB. (1982) «The Credibility of Physically Attractive Communicators", Journal of Advertising 11 (3), 13-23.

Kamins, MA. (1990), " An investigation into the Match-Up Hypothesis in Celebrity Advertising: When Beauty may be Only Skin Deep", Journal of Advertising 19 (1), 413.

Kelman, H and Hovland, CI. (1953) "Reinstatement of the communicator or in Delayed Measurement of Opinion", Journal of Abnormal and Social Psychology 49, 327335.

Leavitt, C.and Karen, KE. (1975) " Mere Similarity versus Information Processing : An Exploration of Source and Message Interaction", Communication Research July ( 2) , 300-06.

McCracken, G. (1989), "Who is the Celebrity Endorser? Cultural Foundations of the Endorsement Process", Journal of Consumer Research December 16, 310-321,

McDonough, J. (1995) " Bringing brands to life», Advertising Age Midwest Region Edition Chicag Spring 66, 3.

McGarry, J and Hendrich, C. (1974), "Communicator Credibility and Persuasion", Memory and Cognition Janurary (2), 82-86.

McGuire, W J. (1968), " Personality and Suceptibility to social influence», in Borgotta, EF and Lambert, ww, Handbook of Personality Theory and Research, 
Chicago, in Jaoued, L.

Efficacité de l'Endossement par les célébrités en publicité : Rôle médiateur de la congruence avec l'image de soi", Actes $\mathrm{du} 23^{\text {ième }}$ Congrès International de l'AFM, 31 Mai -1er Juin 2007, Aix-les -Bains.

Mehta, A. (1994)," How Advertising Response Modelling (ARM) Can Increase Ad Effectiveness », Journal of Advertising Research 34 (3), 62-74.

Mehulkumar, P. (2005), «An Examination of Universal Personality endorser en the interaction between PCI and PBI», Leeds University Business School Report December (2).

Menon, K. (2001), “Celebrity Advertising: An Assessment of Its Relative Effectiveness".

Muehling, DD and Lacziniak, RN. (1988), " Advertising Immediate and Delayed Influence on Brand Attitude: Considerations Accross MessageInvolvement Levels », Journal of Advertising 17 (4), 23.

Ohanian, R. (1991)," The Impact of Celebrity Spokespersons'Perceived Image on Consumers Intentions to Purchase, Journal of Advertising Research February / March 31 (1),46-54.

Ohanian, R. (1990), «Constraction and Validation of a Scale to Measure Celebrity Endorsers Perceived Expertise, Trustworthiness and Attractiveness ", Journal of Advertising 19 (3), 39-52.

O'Mahony, S and Meenaghan, T. (1997/1998), " Research the Impact of Celebrity Endorsements on Consumers », In: New Ways for Optimizing Integrated Communications, the Netherlands, ESCOMAR, 1-16.

Patzer, GL. (1983), “An Experiment Investigating the Influence of Communicator Physical Attractiveness on Attitudes", in Proceeding of AMA Eductors Conference, Eds. Murphy P.e.
Petroshius, SM and Crocker, KE.(1989), «An Empirical Analysis of Spokesperson Characteristics on Advertisement and Products Evaluations, " The Academy of Marketing Science, 17(3), 217-225.

Pornpitakpan, C. (2003) «The Effect of Celebrity Endorsers Perceived Credibility on Product Purchase Intention: The Case of Singaporeans », Journal of International Consumer Marketing, 16 (2), 55-74.

Pringle, $\mathrm{H}$ and Binet, L. (2005) «How marketers can use celebrities to sell more effectively ", Journal of Consumer Behaviour March 4 (3), 201-214.

Rhine, R. J and Laurence JS. (1970) "Ego Involvement, Discrepancy, Source Credibility and Attitude Change", Journal of Personality and Social Psychology October 16 , 175-90.

Ross, JA. (1989) "Influence of Expert and Peer Upon Negro Mothers of Low Socioeconomic Status", Journal of Social Psychology, 79-84.

Rossiter, JR. (1982), «Visual Imagery: Application to the Advertising », Advances in Consumers Research 9, 101-109.

Roussel, P and al. (2002) Méthodes d'Equation Structurelles: Recherches et Applications en Gestion, Ed, Economia,.

Roy, S. (2006), "An Exploratory Study in Celebrity Endorsements", Journal of Creative Communications 1(2), Sage Publications New Delhi.

Stafford, (1998). cité par, Jaoued- Abassi, L. (2006) , «L'Endossement par la Célébrité en Publicité: Revue de la Littérature", Université Paul Cezanne, Marseille(2006), 19-20.

Thiétart, RA and all. (2003) Méthodes de Recherche en Management, 2ème édition, Dunod, Paris.

Till, BD and Busler, M. (2000), « The Matchup Hypothesis, Physical Attractiveness, Expertise and the Role of Fit on Brand Attitude », Purchase Intent and Brand 
Beliefs », Journal of Advertising 29 ( 3), Fall, 15.

Tom, G, Clark, R, Elmer, L, Grech, E, Masetti, J, Sandhar, H. (1992), " The Use of Created versus Clebrity Spokesperson in Advertisements", Journal of Consumer Marketing 20 (4), 535-547.

Walker, M, Langemeyer, L, and Langemeyer, D. (1992), " Celebrity Endorsers: Do You Get What You Pay For?" Journal of Service Marketing 6 (4), 35-42.
Wilson, EJ and Sherell, DJ. (1993), " Source Effects in Communication and Persuasion Research: A Meta - Analysis of Effect Size", Journal of the Academy of Marketing Science 21 (2), 101-112.

Woodside, AG and Devenport, W. (1974) "The Effect of Salesman Similarity and Expertise on Consumer Purchasing Behavior", Journal of Marketing Research May 11, 198-202. 